\title{
Thallium in coal: Analysis and Environmental
}

\section{implications}

M. Antonia López Antón ${ }^{1}$, D. Alan Spears ${ }^{2}$, Mercedes Díaz Somoano ${ }^{1}$

M. Rosa Martínez Tarazona ${ }^{1}$

1.-Instituto Nacional del Carbón (CSIC), C/ Francisco Pintado Fe 26, 33011, Oviedo Spain

2.-University of Sheffield, Sheffield S102TN, UK.

Corresponding author: marian@incar.csic.es

Key words: Thallium in coal, Analysis of Thallium, Thallium in coal combustion

\begin{abstract}
The ecotoxicological importance of thallium stems from its acute toxicity, the effects of which are as harmful to living organisms as those of lead and mercury. The main anthropogenic sources of thallium are the emissions from coal combustion processes, underlining the need to control this element in coal and coal by-products. Despite the threat posed by thallium, very little information has been published on its behaviour in coal-fired power plants or on its modes of occurrence in coal, its mobilisation and its distribution. Although thallium is highly toxic, the environmental risk presented by this element in coal utilization have been studied to a much lesser degree than in the case of other toxic elements such as lead, cadmium or mercury. The present work addresses the issue of thallium in coal, focussing on its origin, modes of occurrence, the analytical methods commonly used for its determination and its behaviour during coal utilization for energy production.
\end{abstract}




\section{Introduction: The importance of evaluating thallium behaviour in coal}

The toxic effects of thallium $(\mathrm{Tl})$ have long been recognized and have been frequently observed in animals and humans. Although the precise mode of toxicity is unclear [1], it has been reported to be an element that is more acutely toxic than lead, mercury and cadmium [2-3]. It has been suggested that $\mathrm{Tl}$ may interfere with vital potassium-dependent processes, since thallium ions and potassium ions are similar in size [4]. Thallium remains in the air, water, and soil for a long time and does not decompose. Some $\mathrm{Tl}$ compounds are washed down by the rain and snow into the soil and plants. Eventually it enters the food chain and accumulates in fish and shellfish [5]. Thallium occurs in two oxidation states, $\mathrm{Tl}(\mathrm{I})$ and $\mathrm{Tl}(\mathrm{III})$, the latter being more toxic. The oxidation state of $\mathrm{Tl}$ affects its complexation and subsequent bioavailability and toxicity [6-7]. Early literature claims that $\mathrm{Tl}$ (I) is the most abundant species in nature and suggests that trivalent $\mathrm{Tl}(\mathrm{III})$ is unlikely [8]. Although the thermodynamic stability supports this claim, there is evidence that the most abundant $\mathrm{Tl}$ species in sea and lake waters is $\mathrm{Tl}(\mathrm{III})$ [9-11]. The oxidation of $\mathrm{Tl}(\mathrm{I})$ to $\mathrm{Tl}(\mathrm{III})$ in the environment has been reported to be due to the activity of bacteria [12]. In accordance with Twining et al [7], planktonic bacteria are responsible for oxidizing the thermodynamically stable $\mathrm{Tl}(\mathrm{I})$ to the more abundant Tl(III).

Exposure to high levels of $\mathrm{Tl}$ can have harmful effects on the health $[2,13]$. Some of the effects of $\mathrm{Tl}$ poisoning include: hair loss, the gradual development of mild gastrointestinal disturbances, encephalopathy, tachycardia degenerative changes in the heart, liver and kidney, alterations of the central nervous and cardiovascular systems and eventually death [14-18]. Thallium is considered a priority pollutant by the Environmental Protection Agency (EPA) of the United States (US), and has been classified as a dangerous substance by the European Union (Directive 67/548/EEC). 
The industrial facilities that produce or use $\mathrm{Tl}$ and its compounds are not the major sources of $\mathrm{Tl}$ release to the environment. The main sources are industrial processes where $\mathrm{Tl}$ is present as an impurity in the raw materials. This is the case of coal-fired power plant, smelting operations (mainly lead and zinc) and the cement industry [1920]. It is estimated that about 2.000-5.000 tons per year of $\mathrm{Tl}$ are mobilised by these industrial processes, and in the US about 1000 tons of $\mathrm{Tl}$ are released annually into the environment, 350 tons of which are emitted in the form of vapours and dusts, 60 tons bound to non-ferrous metals and more than 500 tons in fluid and solid wastes. From the available data it can be inferred that power generating plants are the main sources of $\mathrm{Tl}$ emission into the atmosphere [21-23]. Thallium concentration in most coals ranges from 0.5 to $3 \mathrm{mg} \mathrm{kg}^{-1}$ and it has been calculated that about half of this is emitted into the atmosphere [24]. Emissions of $\mathrm{Tl}$ in the flue gases of coal-fired power-generating plants may amount to $700 \mu \mathrm{g} \mathrm{m}^{-3}$, reaching up to $2500 \mu \mathrm{g} \mathrm{m}^{-3}$ in those from cement plants. In the case of cement plants, coal is not the main source of Tl. The raw materials used for cements such as ashes or certain additives may contain higher amounts of $\mathrm{Tl}$ than coal. Generally speaking in both coal combustion and cement production, $\mathrm{Tl}$ volatilizes at high temperatures and condenses on the surface of ash particles in the cooler parts of the system. As a result, $\mathrm{Tl}$ could be 2 to 10 times more concentrated in the fly ashes than it was in the coal before combustion [25-26]. The concentrations of $\mathrm{Tl}$ reported to be emitted on airborne fly ash from coal-burning power plants range from 29 to $76 \mu \mathrm{g} \mathrm{g}^{-1}$, and these increase with decreasing particle size. The highest concentrations have been found on particles with a size of less than $7.3 \mu \mathrm{m}$ in diameter. Such particles are the most dangerous since they are able to pass through conventional particle retention devices in power-generating plants and remain suspended in the atmosphere. They may eventually be deposited in the lower respiratory tract $[25,27]$. 
There are not regulations for the $\mathrm{Tl}$ content of ambient air. However, the EPA has established a maximum contaminant level (MCL) for $\mathrm{Tl}$ in drinking water and waste water (effluent) of 0.002 and $0.14 \mathrm{mg} \mathrm{L}^{-1}$, respectively. Moreover there is a threshold limit value (TLV) of $0.1 \mathrm{mg} \mathrm{m}^{-3}$ for $\mathrm{Tl}$ in the air of any work place. This standard has been adopted by the Occupational Safety and Health Administration (OSHA) and has been signed by the American Conference of Governmental Industrial Hygienists (ACGIH). In addition to these regulations, the EPA requires that discharges or accidental spills into the environment of 1.000 pounds or more of $\mathrm{Tl}$ be reported and the National Institute for Occupational Safety and Health (NIOSH) has recommended that $15 \mathrm{mg} \mathrm{m}^{-3}$ of $\mathrm{Tl}$ be considered as an immediate threat to life and health [2, 22, 28-29].

\section{Methods for analysis of thallium in coal and sub-products}

Several methods are available for determining of $\mathrm{Tl}$, their effectiveness depending on the type and quantity of the sample to be analysed $[25,29]$. Techniques such as inductively coupled mass atomic emission spectrometry (ICP-AES), graphite furnace atomic spectrometry (GF-AAS), radiochemical neutron activation analysis (NAA) or inductively coupled plasma mass spectrometry (ICP-MS) have been used to determine $\mathrm{Tl}$ in meat and food products, urine and blood, biological and environmental samples and water $[19,30-32]$. These techniques have sufficient detection limits $\left(0.1 \mu \mathrm{g} \mathrm{kg}^{-1}\right)$ and are well-suited to applications where a high degree of sensitivity is required for small amounts of sample. For the analysis of $\mathrm{Tl}$ in coal and coal combustion byproducts several methods of analysis have been evaluated including some of the techniques mentioned above [33-35]. In all of them it is necessary to perform a very careful sample preparation procedure to avoid the loss of $\mathrm{Tl}$ or to get out of any contamination. The collection and treatment of the sample prior to analysis requires 
special attention in the case of coal as there is a lack of certified reference materials (CRMs) for $\mathrm{Tl}$ in coal samples ([36]. Thallium is almost always determined as total metal for which, in most of the techniques already mentioned, the samples need to be in solution. In the case of coal samples the first step is to oxidize of the organic matter usually by combustion at low temperatures $\left(300-500^{\circ} \mathrm{C}\right)$, in order to obtain the ashes. These are then subjected to acid digestion by means of a mixture of concentrated hydrofluoric and nitric acids in order to extract the Tl. Digestion must be carried out in a closed vessel to avoid losses from volatilization. Nowadays digestion in Teflon high pressure digestion vessels in microwave ovens is the simplest and quickest option. Alkaline fusion with lithium metaborate followed by dissolution in acid is also a wellknown method to bring coal ashes into solution. However, this method entails the risk of losses of $\mathrm{Tl}$ due to volatilisation. When four methods for decomposing coal fly ash samples using only nitric acid or a mixture of nitric, hydrochloric and hydrofluoric acids were compared, the best results were obtained using a mixture of acids for digestion in a microwave oven [34-37]. The complete decomposition of the fly ashes was not achieved when only nitric acid was used and occasional losses of $\mathrm{Tl}$ occurred when a bomb instead a microwave oven is employed.

In general, the direct analysis of solid samples has a number of advantages over analysis in solution. For example, the risk of contamination or loss of analyte is less likely [38]. However, these methods also have important limitations such as the manner of sample introduction, which can be problematic and a more complex method of calibration. [39]. Unsatisfactory results were found when $\mathrm{Tl}$ was analyzed in a coal by direct solid sampling in a conventional GFAAS device using deuterium background correction [35]. However, more satisfactory results were obtained by direct solid sampling of coal and fly ash and using a high-resolution continuum-source GFAAS to 
eliminate spectral interferences. These results were compared to those obtained by ICPMS using electrothermal vaporization (ETV) and analyte addition and/or isotope dilution (ID) [36]. Although no CRM was available for validating the method the results were considered accurate. The data obtained for coal samples and one fly ash by direct solid sampling without a modifier, adding palladium to the solution and using ruthenium as a permanent modifier were similar, demonstrating the soundness of the high-resolution continuum-source (HR-CS) AAS technique. In this way, HR-CS AAS was proved to be a powerful tool for detecting and eliminating spectral interferences.

Most analytical methods used to measure trace element concentrations are subject to interferences. Spectral interferences are typical in techniques such as ICPAES and ICP-MS [40], but matrix effects are the most common in almost all of the techniques. Matrix interferences are especially important in coal analysis because coals are complex samples that contain various mineral species in different proportions and almost all the elements. The ETV method mentioned above is one of the most suitable ways to introduce a coal extract into an ICP-MS, since the solvent and part of the matrix can be removed by selective volatilization during the temperature program. By introducing a dry sample vapour into the plasma, several spectral and non-spectral interferences can be avoided, and a higher sensitivity and a lower consumption of sample can be achieved [36].

In summary, there are several methods available for the determination of $\mathrm{Tl}$ in coal and coal combustion by -products, but GFAAS and ICP-MS are the routine methods employed by most laboratories. They require very careful sample pre-treatment in order to avoid loss though volatilization and to ensure the complete decomposition of the samples. Direct solid sampling by GFAAS, especially coupled to the high-resolution continuum-source AAS may also provide acceptable results. 


\section{Thallium: location within coal}

According to Goldschmidt 1954 [8], the geochemistry of thallium is well known. The univalent $\mathrm{Tl}$ has an ionic radius very similar to that of $\mathrm{Rb}$ and both are concentrated in late-stage magmatic $\mathrm{K}$ rich minerals such as feldspars and micas. Mica is the most relevant for coals. However, $\mathrm{Tl}$ is not only a lithophil element, but also, and possibly predominantly, a chalcophil element [8]. The mode of occurrence of $\mathrm{Tl}$ in coal has not been studied in great detail [41], but nevertheless it is generally considered that is mainly present in sulphides [42-43]. Thallium concentrations of up to $46 \mu \mathrm{g} \mathrm{g}^{-1}$ (ash basis) have been detected in high-As, high-S lithotypes in the Pond Creek coal bed in Pike and Martin counties, eastern Kentucky [44]. The high concentrations could be attributable to $\mathrm{Tl}-\mathrm{As}$ substitution in pyrite, which is supported by the correlation of $\mathrm{Tl}$ and As with the pyritic sulphur. In a later work [45], $\mathrm{Hg}$ and other trace elements, including $\mathrm{Tl}$, in pyrite and marcasite from the Manchester coal bed, Clay County, Kentucky were detected by scanning proton microprobe (Micro-PIXE). Concentrations of $\mathrm{Tl}$ were found to be highly variable. This had also been noted in Fe-sulphides from the Fire Clay coal bed, eastern [46].

When direct analysis of Fe sulphides were undertaken in UK coals using synchrotron radiation XRF (SXRF) [47], $\mathrm{Cu}, \mathrm{Ni}, \mathrm{As}, \mathrm{Se}$, and $\mathrm{Pb}$ were detected in nearly all the analyses while $\mathrm{Tl}$ was detected in about half of them. Overall individual element concentrations were observed to be highly variable, as in the works cited above. The minimum spacial resolution of SXRF at that time (1989) was $20 \mu \mathrm{m}$ and as a consequence the study was restricted to cleat and concretionary pyrite. Laser ablation ICP-MS, another direct method of analysis, is also increasingly being used to evaluate trace element associations. This method was employed to study a well-characterised Spanish coal using a beam diameter of $10 \mu \mathrm{m}$, which is smaller than that applied in the 
other instrumental methods described above [48]. Different forms of Fe sulphide were analysed and a concentration of $11 \mu \mathrm{g} \mathrm{g}^{-1}$ of $\mathrm{Tl}$ was recorded for pyrite. More recently laser ablation ICP-MS was used to study trace element distributions in macerals and the importance of pyrite as a host for trace elements was demonstrated [49].

The principal methods for determining trace element locations in coals are indirect and are based mainly on the statistical analysis of geochemical data from a suite of coal samples representing one or more coals. Because this paper is a review of methods of analysis it is appropriate to consider also statistical analysis, particularly as a number of issues related to statistics have recently been raised [50]. Statistical methods can provide useful insights into trace element modes of occurrence in properly constrained suites of samples. One such constraint is that the sample size should be large enough for the results to be statistically significant while another is that, as far as possible, the populations should be homogeneous. Thus coal samples from different provinces should not be combined because geological factors are all important in determining their geochemistry. It is also recommended [50] that only coals with a limited range of ash content should be analysed. However, this is not something with which we would totally agree. If the ash is derived mainly from the detrital minerals, as in the UK, then suppressing this variation would make it more difficult to identify the elements associated with this fraction. However, as it has been noted [50], once this variation is suppressed other relationships may become more apparent. It is also true that the greater the amount of independent information available (i.e. mineralogy or petrography), the more reliable the statistical results will be [50]. An important aspect of correlation analysis not dealt with is the problem of dealing with a system in which the components total $100 \%$, which means that if any of the major components increases, then one or more of the other components must decrease in what is a closed system 
[51]. Significance levels are then affected and spurious correlations may arise. Some works [52-53] advocated the use of a log-ratio transform to overcome this problem and others [54] demonstrated the validity of this approach. When a representative suite of UK coals was analysed using energy dispersive polarised XRF [55], it was found that the elements $\mathrm{As}, \mathrm{Mo}, \mathrm{Sb}, \mathrm{Se}$ and $\mathrm{Tl}$ had a significantly positive relationship to $\mathrm{Fe}$, which they attributed to pyrite. In a follow up work on the Parkgate coal in the UK [56], T1 and other elements were analysed by ICP-MS, which enhances detection limits. From the log-ratio transforms it was concluded that pyrite contained nearly all of the $\mathrm{Hg}, \mathrm{Tl}$, As and Se and most of the Mo, Cd, Ni and Sb. All of these elements have been recorded in pyrite [57], either as inclusions or substituted either stoichimetrically or nonstoichimetrically. The latter case is thought to apply to $\mathrm{Tl}$ with $\mathrm{Tl}^{3+}$ replacing for $\mathrm{Fe}^{2+}$ to compensate for the charge imbalance resulting from $\mathrm{AsS}^{3-}$ substituting for the $\mathrm{S}_{2}{ }^{2-}$ dianion. Other cations that behave in a similar manner to $\mathrm{Tl}$ are $\mathrm{Mo}^{3+}$ and $\mathrm{Au}^{3+}$. In the work on the Parkgate coal [56] statistical analysis was limited to correlation matrices and bivariate plots, which has the advantage that close contact is maintained with the data. The value of graphical output in statistical analysis has been well documented and [58]. Some of the statistical relationships concerning $\mathrm{Tl}$ in the Parkgate coal are shown in Figure 1. The bivariate plots have correlation coefficient $r$ (Pearson product moment) ranging from 0.95 to 0.87 using centred $\log$ transformed data. These values exceed the 99.9\% confidence level. Not only can the significance of the correlations be tested but also the significance of the intercepts. Only in the case of the Fe vs S plot is the intercept significant. As the Fe value tends to zero there remains some residual $\mathrm{S}$ which is not present in pyrite. This is the organic $\mathrm{S}$ and the intercept value corresponds to the value determined by conventional methods. The use of intercept values has long been used by geochemists. Essentially this was the approach adopted by [8] to demonstrate 
the Ge-organic association. From the discussion above it should be noted that the inverse relationship results from the closed system and also that the composition of the organic matter can vary with ash content. The bivariate plots in Figure 1 for $\mathrm{Tl}$ all have intercept values which are not significantly different to zero. This means that $\mathrm{Tl}$, like $\mathrm{Hg}$, is predominantly present in pyrite. The slope of the Fe vs $\mathrm{S}$ regression equation corresponds to the composition $\mathrm{FeS}_{2}$. Although $\mathrm{Fe}$ is present in the clay minerals their contribution to the Fe variation is minor and could at most be responsible for some of the scatter on the Fe vs S plot. The above discussion, based on the correlation matrices and bivariate plots, demonstrates that pyrite is the main location for $\mathrm{Tl}$ in these coals.

It was pointed out earlier that some $\mathrm{Tl}$ will probably be present in illite in particular because of the similarity in ionic size of univalent $\mathrm{Tl}$ and $\mathrm{K}$ and $\mathrm{Rb}$. On the basis of the analyses of mudrocks associated with the Parkgate coal [56] it is possible to calculate the contribution of the clay minerals to the $\mathrm{Tl}$ content of the coals assuming that all the $\mathrm{Tl}$ is present in the clays and the element ratios remain constant from mudrock to coal. Using the $\mathrm{Tl} / \mathrm{K}$ and $\mathrm{Tl} / \mathrm{Rb}$ ratios for the mudrock, and applying to the $\mathrm{K}$ and $\mathrm{Rb}$ concentrations in the coal, [56] gives, for both ratios, a $\mathrm{Tl}$ concentration of the clays in the coal of $0.02 \mu \mathrm{g} \mathrm{g}^{-1}$, compared with the median concentration in the coal for Tl of $0.33 \mu \mathrm{g} \mathrm{g}^{-1}$. That is to say the clay minerals, essentially the detrital fraction, account for not more than $5 \%$ of the $\mathrm{Tl}$ in the coal, which supports the conclusion that pyrite is the dominant location for this element in the coal.

The fact that pyrite can be regarded as the main location of $\mathrm{Tl}$ in the coal, has several implications. One of these is that the association of environmentally sensitive trace elements such as $\mathrm{Tl}$ with the Fe sulphide minerals raises the possibility of precombustion cleaning by physical cleaning methods, in which the sulphides usually are separated together with the coaly matter [44]. 


\section{The behaviour and fate of thallium during coal conversion processes}

During coal conversion processes trace elements are partitioned between the slag/bottom ash, fly ash and flue gas according to their volatility, their mode of occurrence in the coal, the conversion technology, the operational parameters and the existing air pollution control devices [20, 59-63]. Different classifications for trace element behaviour during coal combustion processes, based on theoretical or experimental studies have been proposed. These classifications are divided into three main groups [20]: Group 1 includes the non-volatile elements which are concentrated in the coarse residues, or are partitioned equally between the coarse residues and particulates (Ba, Ce, Cs, Mg, Mn, Th); Group 2 comprises the volatile elements that condense on ash particles, even on the fine-grained particles, which may escape the particle control systems (As, $\mathrm{Cd}, \mathrm{Cu}, \mathrm{Pb}, \mathrm{Sb}, \mathrm{Zn}$ ) and Group 3 includes the high volatile elements, which are concentrated in the vapour or gas phase and are depleted in all the solid phases (Br, Hg, I). Several elements may show partitioning behaviour intermediate between group 1 and $2(\mathrm{Cr}, \mathrm{Ni}, \mathrm{U}, \mathrm{V})$ or between 2 and $3(\mathrm{Se})$. Trace elements show a similar behaviour during the gasification processes. In most of the studies $\mathrm{Tl}$ has been assigned to group 3.

In 1995 a detailed investigation into the behaviour of more than 30 trace elements during coal combustion at a large power station was performed [63]. In this study $\mathrm{Tl}$ was found enriched in fly ashes, and behaved like an element that volatilizes and subsequently partially condenses on the particles. Elements of this type may be adsorbed onto calcium oxides in a similar way to the excess of sulphur fixation $(\mathrm{CaO}+$ $\mathrm{SO} 3=\mathrm{CaSO} 4)$. As a consequence, the potential toxicity of fly ashes increases, since $\mathrm{Tl}$, like most of the volatile toxic elements, is concentrated in breathable particles. Thallium is only partially retained in the solid combustion by-products but is mainly present in 
phases as sulphates, which can easily leach in natural environment conditions [64]. The high lime and anhydrite content of fly ashes may explain the enrichment of $\mathrm{Tl}$ in this fraction [65]. By means of thermodynamic equilibrium calculations it was found that the amount of chlorine in coal had a considerable influence on the volatilization of $\mathrm{Tl}$, due to the formation of thermodynamically stable compounds with chlorine [66].

The available literature on $\mathrm{Tl}$ behaviour during coal gasification processes is scarce. It is commonly accepted that trace element behaviour during gasification processes is similar to that observed during combustion. However, some exceptions have been pointed out. Reducing conditions promote the volatility of $\mathrm{Tl}$ due to the formation of highly volatile species such as chlorides. The evaluation of the partitioning of $\mathrm{Tl}$ in a pressurised entrained flow gasifier, working under slagging conditions at $1200-1600{ }^{\circ} \mathrm{C}$ and 25 bar, fed with a mixture of a high volatile bituminous coal rich in metals and a pet-coke, with limestone (2-4\%) as a fluxing agent [67], has demonstrated that $\mathrm{Tl}$ behaves like a moderately volatile element up to $40 \%$ it being distributed in gas phase and $60 \%$ in the fly ash.

In recent years fuels other than coal have been blended with this combustible in order to reduce $\mathrm{CO}_{2}$ emissions and the effect of these co-fuels on trace element emissions has also been evaluated [68]. In experiments with two coals (one Polish, one Colombian), four biomass fuels (wood-bark, straw, pulp sludge, and paper sludge), and three waste fuels (agricultural waste, sewage sludge and plastic waste), Tl was observed to have been almost completely volatilized from the Colombian coal/straw combustion, almost completely retained by sewage sludge ash and partially volatilized from all of the other fuels. When combustion in a continuous low airflow of sludge, coal and sludge and coal blends was compared, a similar T1 behaviour was observed in all cases [69-70]. Because $\mathrm{Tl}$ is included among the elements regulated by the 2000/76/EC Directive, it 
should be borne in mind that sludge could negatively affect the emissions of Tl. During the co-combustion of sewage sludge with wood [71], the retention capacity of fly ash and the influence of reducing and oxidising conditions, the type of sludge and the addition of lime on the distribution of trace elements was also evaluated. Thallium is volatilized at $850{ }^{\circ} \mathrm{C}$ in an oxidising atmosphere and in reducing conditions, the volatility of this element increases.

Theoretical predictions are a useful tool for studying the behaviour of trace elements during coal conversion processes. Several works on trace element behaviour during coal conversion processes have been performed using theoretical data. The first authors to consider $\mathrm{Tl}$ in these studies were Yan et al.[72-73]. Theoretical predictions under oxidizing conditions at temperatures below $550 \mathrm{~K}$, showed two solid and two condensed $\mathrm{Tl}$ species as the major species: $\mathrm{TlCl} 3(\mathrm{~s})(300-350 \mathrm{~K})$ and $\mathrm{TlAsO} 4(\mathrm{~s})$ (below $550 \mathrm{~K}$ ), $\mathrm{TlCl}(\mathrm{cr}, 1)$ (at around $400 \mathrm{~K}$ ), and $\mathrm{Tl} 2 \mathrm{SO} 4(\mathrm{cr}, 1)$ (at around $450 \mathrm{~K}$ ). At higher temperatures, several gaseous $\mathrm{Tl}$ halides and the gaseous atom $[\mathrm{Tl}(\mathrm{g})]$ became dominant: $\mathrm{TlBr}(\mathrm{g})(600-1600 \mathrm{~K}), \mathrm{TlCl}(\mathrm{g})(500-1800 \mathrm{~K}), \mathrm{Tl}(\mathrm{g})$ (above $1500 \mathrm{~K})$ and a small quantity of $\mathrm{TlF}(\mathrm{g})(; 1600 \mathrm{~K})$. Under reducing conditions $\mathrm{TlI}(\mathrm{cr}, \mathrm{l})(300 \mathrm{~K})$, T12S(cr,l) $(350 \mathrm{~K}), \mathrm{T} 12 \mathrm{Se}(\mathrm{s})(400 \mathrm{~K})$, and $\mathrm{TlBr}(\mathrm{cr}, 1)(450 \mathrm{~K})$ were predominant below $500 \mathrm{~K}$. Then, as in oxidizing conditions, several gaseous thallium halides and the gaseous free atom $(\mathrm{Tl}(\mathrm{g}))$ became dominant: $\mathrm{TlBr}(\mathrm{g})(500-1400 \mathrm{~K}), \mathrm{TlCl}(\mathrm{g})(500-1500 \mathrm{~K}), \mathrm{Tl}(\mathrm{g})$ (above $1100 \mathrm{~K}$ ), and TII(g) (400-1200 K). These results agree with those of Thompson and Argent [74]. They predicted the equilibrium distribution of the major, minor and trace elements in the Pittsburgh $N^{0} 8$ coal for gasification under the conditions of the Prenflo gasifier. Thallium was found to have been almost totally volatilised during the process. 
Problems caused by $\mathrm{CO}_{2}$ emissions into the atmosphere have encouraged the development of technologies for the capture and sequestration (CCS) of this contaminant from coal fired plants. Among them, oxy-fuel combustion is one of the promising technologies. In this new scenario there is a considerable lack of knowledge about how the different conditions may affect the behaviour of trace elements. Because there is no literature on $\mathrm{Tl}$ partitioning in oxy-fuel combustion conditions a theoretical approach was carried out in this work. HSC Chemistry 6.0 software was used to evaluate the possible species of $\mathrm{Tl}$ that may be present in the gas atmospheres described in Table 1. The results obtained point to a similar amount of $\mathrm{Tl}$ in oxy-combustion and combustion in air, $\mathrm{TlO}(\mathrm{g})$ being the most stable species in the whole range of temperature and conditions evaluated (Figure 2).

From the reviewed literature, it has been clearly demonstrated that $\mathrm{Tl}$ is a volatile element under coal conversion processes. Its volatility increases with the chlorine content, which reacts with this element during co-combustion processes and increases under gasification conditions. Gaseous $\mathrm{Tl}$ is partially condensed onto fly ashes which may late become a hazardous waste.

\section{Conclusions}

The findings of this review may be briefly summarized under three main headings.

1.- Thallium is concentrated in pyrite in coals along with other environmentally sensitive elements, notably $\mathrm{Hg}$.

2.- Thallium is an element of environmental concern, present in coal at the level of trace elements and emitted to the atmosphere to different extents in gas phase or in breathable 
particles. The emissions will vary depending not only on the composition and nature of the fuel but also on the combustion conditions.

3.- Because until now insufficient attention has been paid to the problems that $\mathrm{Tl}$ from coal combustion may cause, research on its behaviour has been limited. Accurate methods of analysis and the possibility of avoiding toxic emissions of $\mathrm{Tl}$ to the air or as a leachate need to be investigated.

\section{Acknowledgments}

The authors want to acknowledge the CSIC for providing M. Antonia López-Antón with a postdoctoral position.

\section{Literature}

[1] Saddique A, Peterson CD. Thallium poisoning: a review. Vet Hum Toxicol 1983; 25: $16-22$.

[2] John Peter AL and Viraraghavan T. Thallium: a review of public health and environmental concerns. Environment International 2005; 31: 493- 501.

[3] Maluszynski MJ. Thallium in the environment. Ochrona Srodowiska I Zasobów Naturalnych 2009; 40: 31-37.

[4] Cavanagh JB, Fuller NH, Johnson HR, Ruge P. The effect of thallium salts with particular reference to the nervous system changes. Q J Med 1974; XLIII: 293-319.

[5] http://www.medicinenet.com/thallium/article.htm\#thallium Accessed May 2012.

[6] Ralph L, Twiss M R. Comparative Toxicity of Thallium(I), Thallium(III), and Cadmium(II) to the Unicellular Alga Chlorella Isolated from Lake Erie Bull Environ. Contam. Toxicol 2002; 68: 261-268.

[7] Twining B, Twiss M and Fisher N. Oxidation of Thallium by Freshwater Plankton Communities. Environ. Sci. Technol 2003; 37: 2720-2726. 
[8] Goldschmidt VM. Geochemistry, Clarendon Press, Oxford pg 536; 1954.

[9] Scheckel KG, Lombi E, Rock SA and McLaughlin MJ. In Vivo Synchrotron Study of Thallium Speciation and Compartmentation in Iberis intermedia. Environ. Sci. Technol 2004; 38: 5095-5100.

[10] Batley GE, Florence TM. Determination of thallium in natural waters by anodic stripping voltammetry. Electroanl. Chem. 2004; 61: 205-211.

[11] Lin T S, Nriagu JO. In Thallium in the Environment; Nriagu, J O, Ed.; John Wiley \& Sons Inc: New York, Vol. 29, pp 31-43; 1998.

[12] Lin TS, Nriagu JO. Thallium speciation in the Great Lakes. Environ. Sci. Technol. 1998; 33: 3394-3397.

[13] Viraraghavan T, Srinivasan A. Thallium: Environmental Pollution and Health effects. Encyclopedia of Environmental Health pp 325-333; 2011.

[14] Prick JJG, Sillevis Smitt WG, Muller L Thallium poisoning. Elsevier Publishing Co, Amsterdam, Houston, London, New York; 1955.

[15] Meggs WJ, Hoffman RS, Shih RD, Weisman RS, Goldfrank LR. Thallium poisoning from maliciously contaminated food. J Toxicol Clin Toxicol 1955; 32: 723 30.

[16] Hoffman RS. Thallium poisoning during pregnancy: a case report and comprehensive literature review. J Toxicol Clin Toxicol 2000; 38: 767-75.

[17] Saha A, Sadhu H G, Karnik A B, Patel T S, Sinhá S N, Saiyed H N. Erosion of nails following thallium poisoning: a case report. Occup Environ Med. 2004; 61: 640642.

[18] US Environmental Protection Agency. EPA/635/R-08/001F (2009) Toxicological review of thallium and compounds (CAS No. 7440-28-0). In support of summary information on the Integrated Risk Information System (IRIS) September 2009. www.epa.gov/iris/toxreviews/1012tr.pdf Accessed May 2012. Accessed May 2012. 
[19] Saha A. Thallium toxicity: A growing concern. Indian Journal of Occupational and Environmental Medicine 2005; 9: 53-56.

[20] Clarke LB, Sloss LL. Trace elements-emissions from coal combustion and gasification. IEA Coal Research, London, Chapter 2; 1992.

[21] Nriagu JO. Global metal pollution-poisoning the biosphere, Environment 1990; 32: $7-33$.

[22] Ewers U. Environmental exposure to thallium. The Science of the Total Environment 1988; 71: 285-292.

[23] Kazantzis G. Thallium in the environment and health effects. Environmental geochemistry and health $2000 ; 22: 275-280$.

[24] Smith IC, Carson BL Trace metals in the environment. Vol. I. Thallium. Ann Arbor, MI: Ann Arbor Science Publishers; 1977.

[25] Environmental Health Criteria (EHC) 182. Thallium. International programme on chemical safety World Health Organization Geneva, 1996. WHO Library Cataloguing in Publication Data). $\quad$ http://www.inchem.org/documents/ ehc/ehc/ehc182.htm\#SubSectionNumber:2.4.2 Accessed May 2012.

[26] Davison RL, Natusch DF, Wallace JR, Evans, C A. Trace elements in fly ash: Dependence of concentration on particle size. Environ Sci Technol 1974; 8:1107-1113.

[27] (ATSDR) Agency for Toxic Substances and Disease Registry Toxicological Profile for thallium. (ATSDR) Atlanta, GA: U.S. Department of Health and Human Services, Public Health Service; 1992 www.atsdr.cdc.gov/toxprofiles/tp.asp?id=309 Accessed May 2012.

[28] CCME (Canadian Council of Ministers of the Environment Summary of existing $\begin{array}{llll}\text { Canadian } & \text { environmental } & \text { quality } & \text { guidelines; }\end{array}$ http://www.ccme.ca/assets/pdf/e1_062.pdf. Accessed May 2012.

[29] Sharma J, Sharma RL, Singh HB, Satake M. Hazards and analysis of thallium-A review. Toxicological and Environmental Chemistry 1986; 11: 93-116. 
[30] US Department of Agriculture Food Safety and Inspection Service, Office of Public Health Science, CLG-TM4.01 Detection of Thallium, Arsenic and Mercury using ICP-AES, 1-9; 2006.

[31] Paschal DC, Bailey GG. Determination of thallium in urine with Zeeman effect graphite furnace atomic absorption. J Anal Toxicol 1986; 10:252-4.

[32] Henke G. Thallium determination in biological materials by radiochemical neutron activation analysis. Fresenius J Anal Chem 1991; 339:245-248.

[33] Sager M. Determination of arsenic, cadmium, mercury, stibium, thallium and zinc in coal and coal fly-ash. Fuel 1993; 72: 1327-1330.

[34] Bettinelli M, Baroni U, Pastorelli N. Determination of arsenic, cadmium, lead, antimony, selenium and thallium in coal fly ash using the stabilised temperature platform furnace and Zeeman-effect background correction. J Anal. Atomic Spectrometry 1998; 3: 1005-1011.

[35] Silva AF, Borges DLG, Welz B, Vale MGR, Silva MM, Klassen A, Heitmann U. Method development for the determination of thallium in coal using solid sampling graphite furnace atomic absorption spectrometry with continuum source, highresolution monochromator and CCD array detector. Spectrochimica Acta Part B 2004; 59: $841-850$.

[36] Maia SM, Pozebon D, Curtius AJ. Determination of Cd, $\mathrm{Hg}, \mathrm{Pb}$ and $\mathrm{Tl}$ in coal and coal fly ash slurries using electrothermal vaporization inductively coupled plasma mass spectrometry and isotopic dilution. J. Anal. At. Spectrom. 2003; 18: 330-337.

[37] Figueroa LB, Alvarado JI, Dominguez JR. Graphite furnace atomic absorption determination of $\mathrm{Cu}, \mathrm{Mn}$ and $\mathrm{Ni}$ in coal after sample dissolution by alkaline fusion, At. Spectrosc. 1997; 18: 13- 16.

[38] Belarra MA, Resano M, Vanhaecke F, Moens L. Direct solid sampling with electrothermal vaporization/atomization: what for and how? Trends Anal. Chem 2002; 21: 828-839. 
[39] Nowka R, Müller H. Direct analysis of solid samples by graphite furnace atomic absorption spectrometry with a transversely heated graphite atomizer and D2 background correction system (SS GF AAS). Fresenius J. Anal. Chem 1997; 359: 132137.

[40] Chapnick S D, Pitts LC, Rothman N C. Arsenic and thallium data in environmental samples: fact or fiction?. Remediation 2010; 20: 39-59.

[41] Dai S, Ren D, Chou CL, Finkelman RB, Seredin VV, Zhou Y. Geochemistry of trace elements in Chinese coals: A review of abundances, genetic types, impacts on human health, and industrial utilization. International Journal of Coal Geology 2012; 94: 3-21.

[42] Dai S, Sun Y, Zeng R.Enrichment of arsenic, antimony, mercury, and thallium in a Late Permian anthracite from Xingren, Guizhou, Southwest China. International Journal of Coal Geology,2006; 66: 217-226.

[43] Finkelman RB.Modes of occurrence of environmentally sensitive trace elements in coals. pp 24-50 In: Swaine DJ and Goodarzi F, editors. Environmental aspects of trace elements in coals. Kluwer, Dordrecht; 1995.

[44] Hower JC, Ruppert LF, Eble CF, Clark WL. Geochemistry, petrology, and palynology of the Pond Creek coal bed, northern Pike and southern Martin Counties, Kentucky. International Journal of Coal Geology 2005; 62: 167-181.

[45] Hower JC, Campbell JL, Teesdale WJ, Nejedly Z, Robertson JD. Scanning proton microprobe analysis of mercury and other trace elements in Fe-sulfides from a Kentucky coal. International Journal of Coal Geology 2008; 75: 88-92.

[46] Ruppert LF, Hower JC, Eble CF. Arsenic-bearing pyrite and marcasite in the Fire Clay coal bed, Middle Pennsylvanian Breathitt Formation, eastern Kentucky. International Journal of Coal Geology 2005; 63: 27-35.

[47] White RN, Smith JV, Spears DA, Rivers ML, Sutton SR. Analysis of iron sulphides from U.K. coal by synchrotron radiation X-ray fluorescence. Journal of the Institute of Fuel 1989; 68: 1480-1486. 
[48] Querol X and Chenery S. The determination of trace element affinities in coal by laser ablation microprobe- inductively coupled plasma mass spectrometry. pp137-146 In: Whateley MKG and Spears DA editors, European Coal Geology, Geological Society London Special Publication 82; 1995.

[49] Spears DA, Borrego AG, Cox A, Martinez-Tarazona MR. Use of laser ablation ICP-MS to determine trace element distributions in coals, with special reference to $\mathrm{V}$, Ge and A1. International Journal of Coal Geology 2007; 72: 165-176.

[50] Eskanazy G, Finkelman RB, Chattarjee S. Some considerations concerning the use of correlation coefficients and cluster analysis in interpreting coal geochemistry data. International Journal of Coal Geology 2010; 83: 491-493.

[51] Chayes F. Ratio correlation. The University of Chicago Press, Chicago, 99 p; 1971.

[52] Aitchison J. The statistical analysis of compositional data. Chapman and Hall, London, 416 pp; 1986.

[53] Aitchison J. Logratios and natural laws in compositional data analysis. Mathematical Geology 1999; 31: 563- 580.

[54] Drew LJ, Grunsky EC, Schuenemeyer JH. Investigation of the stucture of geological process through multivariate statistical analysis-the creation of a coal. Mathematical Geosciences 2008; 40: 789-811.

[55] Spears DA, Zheng Y. Geochemistry and origin of elements in some UK coals. International Journal of Coal Geology 1999; 38: 161-179.

[56] Spears DA, Tewalt SJ. The geochemistry of environmentally important trace elements in UK coals with special reference to the Parkgate coal in the YorkshireNottinghamshire Coalfield, UK. International Journal of Coal Geology 2009; 80: 157166.

[57] Abraitis PK, Patrick RAD, Vaughan DJ. Variation in compositional, textural and electrical properties of natural pyrite; a review. International Journal Mineral Processing 2004; 74: 41-59. 
[58] Anscombe FG. Graphs in statistical analysis. American Statistician 1973; 27: 1721.

[59] Clarke LB. Management of by-products from IGCC power generation, IEACR/38, London, UK, IEA Coal; 1991.

[60] Meij R. Trace element behaviour in coal fired power plants. Fuel Process Tech, 1994; 39: 199-217.

[61] Brushell AJ, Willianmson J. e fate of trace elements in coal during gasification. Coal Science. 8th International Conference on Coal Science. Oviedo, Spain, 10-15 Sep 1995, Amsterdam, the Netherlands, Elsevier Science B.V., vol2, 1967-1970; 1995.

[62] Helble JJ, Mojtahedi W, Lyyränen J, Jokiniemi J, Kauppinen E. Trace element partitioning during coal gasification. Fuel 1996; 75:932-939.

[63] Querol X, Fernández-Turiel JL, López-Soler A. Trace elements in coal and their behaviour during combustion in a large power station. Fuel 1995; 74:331-343.

[64] Llorents JF, Fernadez-Turiel JL, Querol X. The fate of trace elements in a large coal-fired power plant. Environmental Geology 2001; 40: 409-416.

[65] Esenlik S, Harayigit AI, Bulut Y, Querol X, Alastuey A, Font O.Element behaviour during combustion in coal-fired. Orhaneli power plant, Bursa-Turkey, Geologic Acta 2006; 4: 439-449.

[66] Danihelka P, Volana Z, Jones JM, Williams A. Emission of trace toxic metals during pulverized fuel combustion of Czech coals. Int. J. Energy Res. 2003; 27, 11811203.

[67] Font O, Querol X, Izquierdo M, Alvarez E, Moreno N, Diez ., Alvarez-Rodriguez R, Clemente-Jul C, Coca P, Garcia Peña F. Partitioning of elements in a entrained flow IGCC plant: Influence of operational conditions. Fuel 2010; 89: 3250-3261.

[68] Miller BB, Kandiyotil R, Dugwell DR. Trace element emissions from cocombustion of secondary fuels with coal: A comparison of bench-scale experimental data with predictions of a thermodynamic equilibrium model. Energy \& Fuels 2002; 16: 956-963. 
[69] Folgueras MB, Diaz RM, Xiberta J, Prieto I. Volatilisation of trace elements for coal-sewage sludge blends during their combustion. Fuel 2003; 82: 1939-1948.

[70] Folgueras MB, Diaz RM, Xiberta J, Alonso M. Effect of inorganic matter on trace element behavior Turing combustión of coal-sewage sludge blends. Energy \& Fuels 2007; 21: 744-755.

[71] Elled AL, Åmand LE, Leckner B, Andersson BÅ. The fate of trace elements in fluidised bed combustion of sewage sludge and wood. Fuel 2007; 86: 843-852.

[72] Yan R, Gauthier D, Flamant G. Volatility and chemistry of trace elements in a coal combustor. Fuel 2001; 80: 2217-2226.

[73] Yan R, Gauthier D, Flamant G. Partitioning of trace elements in the flue gas from coal combustion. Combustion and Flame 2001; 125: 942-954.

[74] Thompson D, Argent B.B. Prediction of the distribution of trace elements between the product streams of the Prenflo gasifier and comparison with reported data. Fuel $2002 ; 81,555-570$. 

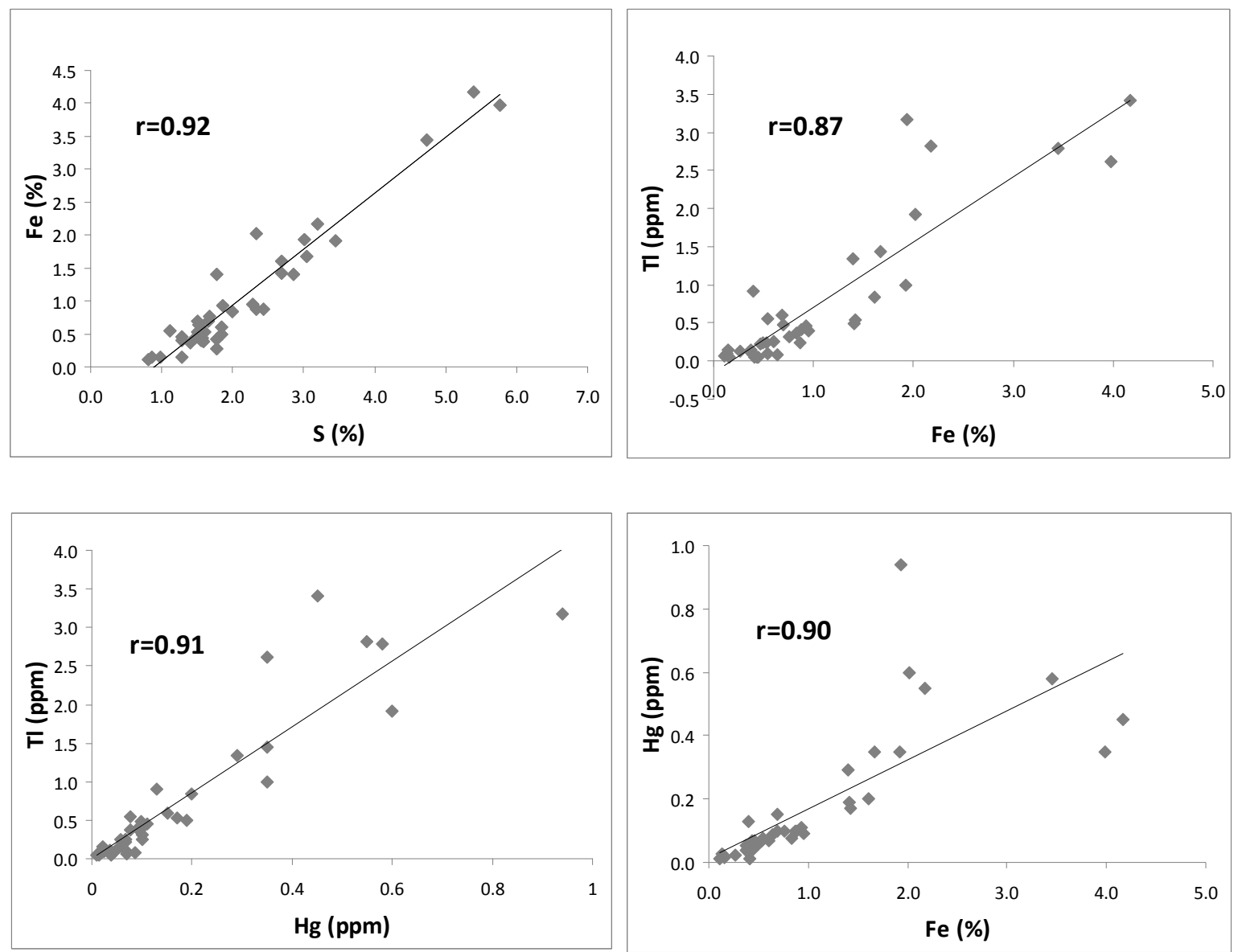

Figure 1. To show selected bivariate plots for Fe, $\mathrm{S}, \mathrm{Hg}$ and $\mathrm{Tl}$ in the Parkgate coal from data in Spears and Tewalt (39). Fe and S are expressed as percentage and $\mathrm{Hg}$ and $\mathrm{Tl}$ as $\mu \mathrm{g}^{-1}$. The correlation coefficients are calculated using log-ratio transforms, whereas the regression equations are based on raw data. 


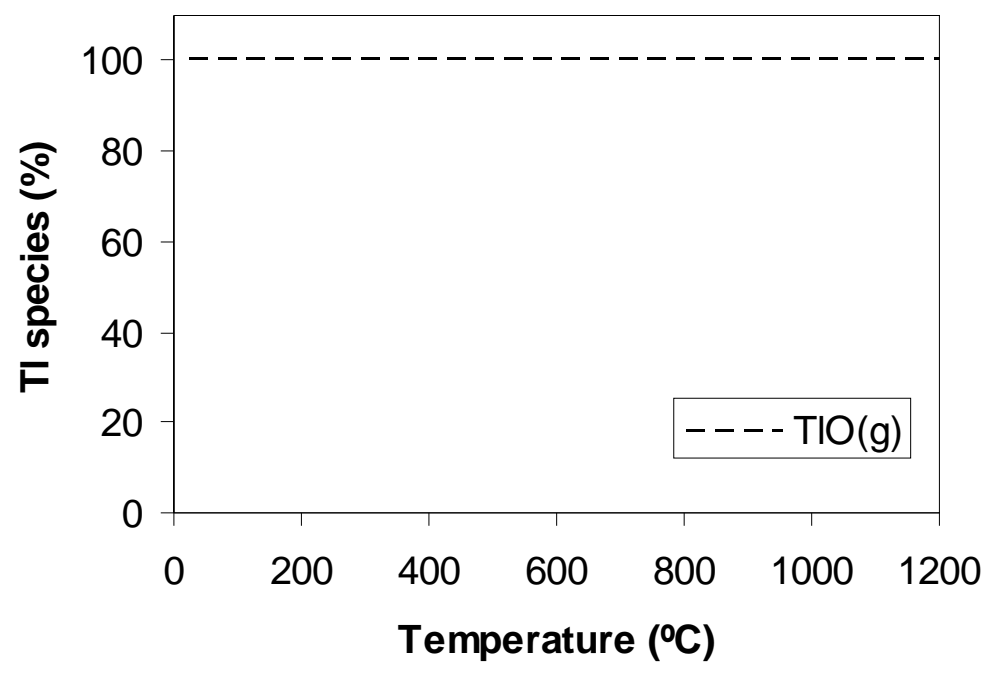

Figure 2. Tl species predicted for oxy-combustion conditions. 
Table 1 Gaseous composition (\%) considered for theoretical predictions by HSC Chemistry.

\begin{tabular}{lllllllllll}
\hline Atmosphere & $\mathbf{C O}$ & $\mathbf{C O}_{2}$ & $\mathbf{H}_{2}$ & $\mathbf{O}_{2}$ & $\mathbf{S O}_{2}$ & $\mathbf{H}_{\mathbf{2}} \mathbf{O}$ & $\mathbf{H}_{2} \mathbf{S}$ & $\mathbf{N}_{2}$ & HCl & $\mathbf{T l}\left(\mu \mathrm{g}^{-1}\right)$ \\
\hline Combustion & - & 15 & - & 9.2 & 0.2 & & - & 69 & - & 1 \\
Oxyfuel IN & & 50 & & 30 & & 20 & & 0 & 1 \\
Oxyfuel Flue gas & - & 25 & - & 4 & - & 70 & - & 1 & - & 1 \\
\hline
\end{tabular}

